\title{
PENERAPAN MODEL SINEKTIK BERORIENTASI BERPIKIR KREATIF DALAM PEMBELAJARAN MENULIS TEKS DESKRIPSI SISWA SMP
}

\author{
Yanti Sri Rahayu \\ Guru SMPN 1 Lembang \\ Email: rahayuyantisri@gmail.com
}

\begin{abstract}
ABSTRAK
Penerapan Model Sinektik Berorientasi Berpikir Kreatif dalam Pembelajaran Menulis Teks Deskripsi Siswa SMP. Tujuan dari penelitian ini adalah untuk mengkaji:(a) Perbedaan kemampuan menulis teks deskripsi siswa yang menggunakan pembelajaran model sinektik dan pembelajaran konvesional, (b) Perbedaan kemampuan berpikir kreatif siswa yang menggunakan pembelajaran model sinektik dan pembelajaran konvensional, (c) korelasi antara menulis teks deskripsi dengan berpikir kreatif. Metode penelitian adalah Mix Method tipe The Embedded Design. Populasi dalam penelitian ini adalah siswa kelas VII SMP Negeri 1 Lembang, dan sampel dipilih secara acak atau (random sampling), yaitu kelas VII A sebagai kelas eksperimen, dan kelas VII B sebagai kelas kontrol. Instrumen yang digunakan instrumen tes dan non tes. Instrumen tes berupa tes kemampuan menulis teks deskripsi berpikir kreatif dan soal non tes berupa angket dan wawancara. Berdasarkan hasil analisis data dan pengujian hipotesis, diperoleh kesimpulan bahwa: Kemampuan menulis teks deskripsi siswa yang menggunakan model sinektik lebih baik dibandingan dengan siswa yang menggunakan pembelajaran konvesional. Kemampuan berpikir kreatif siswa yang menggunakan pembelajaran model sinektik lebih baik dibandingkan dengan siswa yang menggunakan pembelajaran konvesional. Terdapat korelasi antara kemampuan menulis teks deskripsi dengan berpikir kreatif yang menggunakan model pembelajaran sinektik dengan yang menggunakan pembelajaran konvensional. Sedang untuk pembelajaran konvesioanal tidak terdapat korelasi antara menulis teks deskripsi dengan kemampuan berpikir kreatif.
\end{abstract}

Kata Kunci: Model sinektik, berpikir kreatif, dan teks deskripsi.

\begin{abstract}
Text Writing Lessons. The purpose of this research is to examine:(a) the difference of students' descriptive writing skills in classes using conventional model and synnectic model, $(b)$ the difference of students' creative thinking ability in classes using conventional model and synnectic model, (c) the corelation between descriptive text writing and creative thinking ability. Mix Method, The Embedded Design is used as a method of research. The population of this research is the Grade VII (seven) students of SMP Negeri 1 Lembang, while the samples are chosen random sampling: Classroom VII-A as the experiment classroom and Classroom VII-B as the control classroom. The used instruments are test and non-test based instruments. The test instrument includes creatively thought descriptive text writing evaluation while the non-test instruments include questionnaires and interviews. Based on the data analysis and hyphotesis, it is concluded that students' descriptive writing skills using synnectic model are better than the ones using conventional method. Students' creative thinking skills using the synnectic model are better than the ones using conventinal method. There is a corelation between descriptive text writing and creative thinking that uses either or both of the synnectic and conventional method. However, there is no corelations at all if the method used is solely the conventional method.
\end{abstract}

Key words: Oriented Synnectic, Creative Thinking, and Description Text. 


\section{PENDAHULUAN}

Bahasa berperan penting dalam dunia pendidikan, yaitu pada saat menyampaikan materi kepada peserta didik di sekolah khususnya saat menyampaikan materi bahasa Indonesia. Hal ini sesuai dengan pendapat Santoso (1990:1) sebagai berikut. Bahasa adalah alat untuk berkomunikasi, bahwa bahasa adalah serangkaian bunyi yang dihasilkan oleh alat ucap manusia secara sadar, dan bahwa bahasa itu diatur oleh suatu sistem. Sebagai alat untuk berkomunikasi, bahasa harus menampung perasaan dan pikiran pemakainya, serta mampu me-nimbulkan adanya saling mengerti antara penutur dengan pendengar atau antara penulis dengan pembaca.

Pernyataan di atas menunjukkan bahwa bahasa Indonesia sebagai suatu bahasa yang tidak dapat keluar dari sistem yang mengikatnya atau mengaturnya. Salah satu keterampilan yang sering digunakan dalam kegiatan belajar mengajar adalah keterampilan menulis.

\section{KAJIAN TEORETIS}

Keterampilan menulis termasuk keterampilan berbahasa yang dianggap sulit (Alwasilah, 2007:40). Khususnya mengenai menulis, Tarigan (2008:19) mengatakan, bahwa kemajuan suatu bangsa dan negara dapat diukur dari maju atau tidaknya komunikasi tulis bangsa tersebut.

Namun, kenyataannya masih banyak para siswa yang belum mampu mencurahkan ide-idenya ke dalam bentuk tertulis. Seperti yang disampaikan Kurniawan (2014:82) sebagai berikut. Di sinilah siswa mengalami kesulitan. Kenyataan yang sering terjadi dalam pembelajaran: (1) setiap kali ada pembelajaran menulis cerita pasti siswa resah, kebingungan untuk menulis cerita tentang apa; (2) jika masalah yang akan diceritakan sudah ditemukan, siswa juga bingung untuk mengembangkan masalah ceritanya; (3) kebingungan itu membuat siswa merasa menulis adalah materi pelajaran yang lebih sulit dari pelajaran lain.

Kesulitan siswa dalam menyampaikan ide-ide ke dalam bentuk tertulis ini bukan rahasi lagi. Hal ini bisa terjadi diantaranya karena masih rendahnya minat baca siswa.

Menulis deskripsi atau pemerian merupakan sebuah bentuk tulisan yang bertalian dengan usaha para penulis untuk memberikan perincian-perincian dari objek yang sedang dibicarakan (Keraf, 1981:93). Pembelajaran menulis teks deskripsi dapat membantu siswa dalam melatih kepekaaan karena dengan menulis teks deskripsi, siswa dapat menjelaskan secara nyata suatu objek ataupun suasana tertentu. Alwasilah (2007:114), "deskripsi adalah gambaran verbal ihwal manusia, objek, penampilan, pemandangan, atau kejadian".

Pembelajaran menulis teks deskripsi, siswa diharapkan dapat lebih kreatif dalam mengembangkan daya imajinatif dan memecahkan masalah. Oleh karena itu, penulis menggunakan strategi model pembelajaran untuk mempermudah dalam pembelajaran menulis teks deskripsi. Strategi yang digunakan penulis adalah strategi sinektik yang dikembangkan oleh Gordon. Dalam strategi ini dikembangkan unsurunsur yang berbeda dan nyata. Ada empat pandangan yang mendasari kegiatan strategi sinektik menurut Waluyo (2003:187) sebagai berikut. (1) Kreativitas merupakan kegiatan sehari-hari dan berlangsung seumur hidup yang berupa kemampuan untuk problem solving, eksprsif kreatif, empati ensight, dan pengembangan produk baru; (2) Proses kreatif tidak selamanya misterius, akan tetapi mampu dapat diuraikan dan dapat dimanfaatkan untuk melatih indidividu guna kreativitas mereka (3) Kreativitas 
tercipta di segala bidang dan bukan hanya dalam bidang seni: (4) Peningkatan berpikir kreatif untuk individu dan kelompok adalah sama tidak hanya bersifat individuvidual.

Selain model pembelajaran yang variatif dan inovatif, salah satu cara untuk meningkatkan kemampuan menulis teks deskripsi siswa yaitu dengan pemilihan media belajar yang sesuai. Metode dan media pembelajaran diharapkan dapat menyampaikan pesan pembelajaran, sebagaimana dikemukakan $\mathrm{Mu}$ nir, (2008:138) mengenai manfaat media pembelajaran salah satunya untuk menjelaskan materi pembelajaran atau objek yang abstrak (tidak nyata, tidak dapat dilihat langsung) menjadi konkrit (nyata dapat dilihat, dirasakan atau diraba).

Berdasarkan permasalahan yang dihadapi oleh siswa maka dalam penelitian ini penulis mencoba untuk menggunakan model sinektik yang dilengkapi gambar untuk meningkatkan kompetensi dan sikap positif siswa dalam hal menulis kreatif khususnya menulis teks deskripsi. Joyce (2015:267) berpendapat sebagai berikut. Bahwa menulis kreatif satu strategi dari model sinektik dapat langsung diterapkan ke menulis kreatif, bukan hanya karena itu merangsang penggunaan analogi-analogi, tetapi karena ia membantu "memecahkan perangkat (break set)" ketika penulis berusaha untuk memperluas jangkauan perlengkapan yang dapat mereka gunakan untuk mendekati tugas-tugas ekspresif dalan genre yang besifat menjelaskan (expository), persuasif, dan naratif.

Pernyatan di atas menunjukkan bahwa menulis kreatif merupakan menulis yang menggunakan analogi-analogi dan dapat membantu memecahkan masalah.

\section{METODOLOGI PENELITIAN}

Metode penelitian yang akan digunakan dalam penelitian ini meru- pakan Metode campuran (Mixed Method) tipe penyisipan (Embedded Design).

Penelitian ini merupakan penelitian eksperimen, desain yang digunakan adalah desain eksprerimen semu (Quasi Eksperiment) yaitu dilakukan tanpa proses teknik sampel peluang (Fraenkel dan Wallen dalam Indrawan dan Yaniawati, 2014:58), kemudian memilih dua kelas yang setara ditinjau dari kemampuan akademiknya.

Kelompok eksperimen memperoleh perlakuan pembelajaran menulis dengan menggunakan model pembelajaran sinektik, sementara kelompok kontrol memperoleh perlakuan pembelajaran pembelajaran menulis dengan cara konvensional, keduanya juga melakukan soal pretes dan postes. Soal-soal tersebut merupakan soal yang memuat kemampuan menulis teks deskripsi dan kemampuan berpikir kreatif.

\section{HASIL PENELITIAN DAN} PEMBAHASAN

A. Hasil Penelitian

1. Analisis Data Tes Awal Kemampuan Menulis Teks Deskripsi

Analisis data tes awal kemampuan menulis teks deskripsi dari hasil pengolahan data tes awal dari masingmasing kelompok. Rerata kedua kelas tersebut berbeda, kelas kontrol lebih unggul 9,221 dibandingkan kelas eksperimen. Untuk melihat apakah perbedaannya signifikan atau tidak, ma-ka dilakukan tahap kedua yaitu analisis statistik, langkah pertama yang dilakukan adalah uji prasyarat, yaitu uji normalitas dan homogenitas.

\section{a. Uji Normalitas}

Untuk menguji normalitas data tes awal pada kelas eksperimen dan kelas kontrol digunakan uji normalitas Shapiro-Wilk. Nilai Sig. Kelas eksperimen adalah 0,112 dan Kelas kontrol adalah 
0,502 . Keduanya lebih dari nilai $\alpha=$ 0,05 . Sehingga kedua data berdistribusi normal.

\section{b. Uji Homogentias}

Langkah selanjutnya menguji homogenitas varians, untuk menguji homo-genitas varians digunakan uji Levene. Nilai sig. $=0,042$ kurang dari niali $\alpha=0,05$, sehingga data bervariansi tidak homogen. Karena data tersebut berdis-tribusi normal dan bervariansi tidak homogen, maka langkah selanjutnya yang dilakukan adalah menganalisis perbe-daan rerata kedua kelas dengan meng-gunakan uji t'.

\section{c. Uji Kesamaan Dua Rerata Data Tes Awal Kemampuan Menulis Teks Deskripsi (uji-t')}

Karena kedua data berdistribusi normal dan bervariansi tidak homogen, maka uji rerata yang digunakan adalah uji t'.

Nilai Sig. (2-tailed) Equal variances not assumed adalah 0,330 dan lebih dari $\alpha=0,05$, maka Ho diteima, artinya tidak terdapat perbedaan kemampuan awal menulis teks deskripsi kelas eksperimen dan kelas kontrol.

Nilai sig (2-tailed)-nya 0,547) > 0,05 , maka Ho diterima dan $\mathrm{H} 1$ ditolak. Artinya rerata tes awal kemampuan menulis teks deskripsi kelas eksperimen dan kelas kontrol sama. Dari analisis data di atas dapat disimpulkan bahwa pada $\alpha=0,05$, tidak terdapat perbedaan kemampuan tes awal menulis teks deskripsi antara siswa kelas eksperimen dan kelas kontrol.

Model pembelajaran yang diterapkan pada saat penelitian adalah model sinektik pada kelas ekperimen dan pembelajaran konvensional pada kelas kontrol. Rumusan masalah selanjutnya pada penelitian ini adalah untuk melihat kemampuan, Apakah kemampuan menulis teks deskripsi siswa yang mengikuti pembelajaran menggunakan metode sinektik lebih baik dibandingkan dengan siswa yang mengikuti pembelajaran konvensional.

\section{Analisis Data Tes Akhir} Kemampuan Menulis Teks Deskripsi

Analisis data tes akhir kemampuan menulis teks deskripsi dari hasil pengolahan data tes akhir dari masingmasing kelompok. Rerata kedua kelas tersebut berbeda, kelas eksperimen lebih unggul 7,3361 dibandingkan kelas kontrol. Untuk melihat apakah perbedaannya signifikan atau tidak, maka dilakukan tahap kedua yaitu analisis statistik, langkah pertama yang dilakukan adalah uji prasyarat, yaitu uji normalitas dan homogenitas.

\section{a. Uji Normalitas}

Untuk menguji normalitas data tes akhir pada kelas eksperimen dan kelas kontrol digulnakan uji normalitas Kolmogorov-Smirnov. Nilai Sig. Kelas eksperimen adalah 0,078 , karena 0,078 > 0,05 dan Kelas kontrol adalah 0,083, karena 0,083 > 0,05 Keduanya lebih dari nilai $=0,05$. Sehingga kedua data berdistribusi normal.

\section{b. Uji Homogenitas}

Langkah selanjutnya menguji homogenitas varians, untuk menguji homogenitas varians digunakan uji Levene. Nilai sig. $=0,052$ lebih dari niali $\alpha=0,05$, sehingga data bervariansi homo-gen. Karena data tersebut berdistribusi normal dan bervariansi homogen, maka langkah selanjutnya yang dilakukan ada-lah menganalisis perbedaan rerata kedua kelas dengan menggunakan uji t.

c. Uji Kesamaan Dua Rerata Data Tes Akhir Kemampuan Menulis Teks Deskripsi (uji-t)

Karena data berdistribusi normal dan bervariansi homogen, maka uji rerata yang digunakan adalah uji t'. Nilai Sig. (2-tailed) Equal variances assumed adalah 0,000 dan kurang dari $\alpha=0,05$, maka Ho ditolak, artinya kemampuan 
menulis teks deskripsi kelas eksperimen lebih baik daripada kelas kontrol.

Hasil analisis tes awal dan tes akhir dari kelas eksperimen yang menggunakan model sinektik dan kelas kontrol yang menggunakan model konvensional terlihat adanya kenaikan dan penurunan nilai dari tes akhir dan tes awal untuk nilai rataan, standar deviasi, nilai minimu, dan nilai maksimum. Pada tes awal untuk kelas standar deviasi kelas eksperimen didapat 0,776 sedangkan untuk tes khirnya adalah 0,627 .

Saat diberikan tes awal berarti siswa belum mendapatkan materi sehingga berpengaruh pada proses penjawaban. Kemudian untuk tes akhir, siswa sudah melewati tahap pembelajaran yang mendapat materi tersebut dengan menggunakan model pembelajaran sinektik. Pada tabel terlihat ada penurunan nilai standar deviasi sebesar 0,159, Yakni dari hasil tes awal sebesar 0,776 dan tes akhir 0,627 dimana jika standar deviasi lebih kecil adalah lebih bagus. Karena semakin besar nilai standar deviasi, maka semakin besar jarak rata-rata setiap unit data terhadap rataan hitung (mean). Dengan adanya penurunan nilai standar deviasi maka terdapat perubahan yang cukup baik dalam pembelajarannya.

d. Rekapitulasi Data Tes Awal dan Tes Akhir Kemampuan Menulis Teks Deskripsi

Hasil analisis tes awal dan tes akhir dari kelas eksperimen yang menggunakan model sinektik dan kelas kontrol yang menggunakan model konvensional terlihat adanya kenaikan dan penurunan nilai dari tes akhir dan tes awal untuk nilai rataan, standar deviasi, nilai minimu, dan nilai maksimum. Pada tes awal untuk kelas standar deviasi kelas eksperimen didapat 0,776 sedangkan untuk tes akhirnya adalah 0,627.

\section{Analisis Data Tes Awal Kemam- puan Berpikir Kreatif}

Analisis data tes awal kemampuan berpikir kreatif dari hasil pengolahan data tes awal dari masingmasing kelompok. Rerata kedua kelas tersebut ber-beda, namun tidak terlalu besar, kelas kontrol lebih unggul 0,1579 dibandingkan kelas eksperimen. Artinya kemam-puan awal kelas kontrol lebih baik dari-pada kelas eksperimen. Untuk melihat apakah perbedaannya signifikan atau tidak, maka dilakukan tahap kedua yaitu analisis statistik, langkah pertama yang dilakukan adalah uji prasyarat, yaitu uji normalitas dan homogenitas.

\section{a. Uji Normalitas}

Untuk menguji normalitas data tes awal pada kelas eksperimen dan kelas kontrol digunakan uji normalitas Kolmogorov-Smirnov. Nilai Sig. Kelas eksperimen adalah 0,141, karena 0,141 > 0,05 dan Kelas kontrol adalah 0,077, karena 0,077> 0,05 Keduanya lebih dari nilai $\alpha=0,05$. Sehingga kedua data berdistribusi normal.

\section{b. Uji Homogenitas}

Langkah selanjutnya menguji homogenitas varians, untuk menguji homo-genitas varians digunakan uji Levene. Nilai sig. $=0,393$ lebih dari niali $\alpha=0,05$, sehingga data bervariansi homo-gen. Data tersebut berdistribusi normal dan bervariansi homogen, maka langkah selanjutnya yang dilakukan adalah me-nganalisis perbedaan rerata kedua kelas dengan menggunakan uji t.

c. Uji Kesamaan Dua Rerata Data Tes Awal Kemampuan Berpikir Kreatif (uji-t)

Karena data berdistribusi normal dan bervariansi homogen, maka uji rerata yang digunakan adalah uji t'.

Kriteria pengujian hipotesisnya sama seperti uji normalitas dan homogenitas yaitu berdasarkan P-value dengan $\alpha=0,05$, jika sig (2-tailed) $<\alpha$, maka H0 ditolak dan jika sig (2-tailed) $\geq$ 
$\alpha$, maka H0 diterima. Nilai Sig. (2tailed) Equal variances assumed adalah 0,856 dan lebih dari $\alpha=0,05$, maka Ho diteima, artinya tidak terdapat perbedaan kemampuan awal berpikir kreatif kelas eksperimen dan kelas kontrol.

\section{Analisis Data Tes Akhir Kemam- puan Berpikir Kreatif}

Analisis data tes akhir kemampuan berpikir kreatif dari hasil pengolahan data tes akhir dari masing-masing kelompok. Rerata kedua kelas tersebut berbeda, namun tidak terlalu besar, kelas kontrol lebih unggul 0,1579 dibandingkan kelas eksperimen. Artinya kemampuan awal kelas kontrol lebih baik daripada kelas eksperimen. Untuk melihat apakah perbedaannya signifikan atau tidak, maka dilakukan tahap kedua yaitu analisis statistik, langkah pertama yang dilakukan adalah uji prasyarat, yaitu uji normalitas dan homogenitas.

\section{a. Uji Normalitas}

Untuk menguji normalitas data tes awal pada kelas eksperimen dan kelas kontrol digunakan uji normalitas Kolmogorov-Smirnov. Nilai Sig. kelas eksperimen adalah 0,000 , karena $0,000>$ 0,05 dan kelas kontrol adalah 0,005 , karena 0,005 >0,05 Keduanya kurang dari nilai $\alpha=0,05$. Sehingga kedua data berdistribusi tidak normal.

\section{b. Uji Homogenitas}

Langkah selanjutnya menguji homogenitas varians, untuk menguji homo-genitas varians digunakan uji Levene. Kriteria pengujian hipotesisnya sama seperti uji normalitas yaitu berdasarkan P-value dengan $\alpha=0,05$, jika sig $<\alpha$, maka H0 ditolak dan jika sig $\geq \alpha$, maka $\mathrm{H} 0$ diterima. Nilai sig. $=$ 0,001 kurang dari niali $\alpha=0,05$, sehingga data ber-variansi tidak homogen.

\section{c. Uji Kesamaan Dua Rerata Data Tes Akhir Kemampuan Berpikir Kreatif (Uji-t')}

Karena kedua data berdistribusi tidak normal, maka uji rerata yang digunakan adalah uji statistik non parametrik (Uji Mann Whitney U). Nilai Sig. (2tailed) adalah 0,000 dan kurang dari $\alpha=$ 0,05 , maka Ho ditolak, artinya kemampuan berpikir kreatif kelas eksperimen lebih baik daripada kelas kontrol.

Nilai sig (2-tailed)-nya 0,547) > 0,05 , maka Ho diterima dan $\mathrm{H} 1$ ditolak. Artinya rerata tes awal kemampuan berpikir kreatif kelas eksperimen dan kelas kontrol sama. Dari analisis data di atas dapat disimpulkan bahwa pada $\alpha=0,05$, tidak terdapat perbedaan kemampuan awal berpikir kreatif antara siswa kelas eksperimen dan kelas kontrol. Model pembelajaran yang diterapkan pada saat penelitian adalah model sinektik pada kelas ekperimen dan pembelajaran konvensional pada kelas kontrol. Rumusan masalah selanjutnya pada penelitian ini adalah untuk melihat kemampuan, Apakah kemampuan berpikir kreatif siswa yang mengikuti pembelajaran menggunakan metode sinektik lebih baik dibandingkan dengan siswa yang mengikuti pembelajaran konvesional.

d. Rekapitulasi Data Tes Awal dan Tes Akhir Kemamapuan Berpikir Kreatif

Terlihat hasil analisis tes awal dan tes akhir dari kelas eksperimen yang menggunakan model sinektik dan kelas kontrol yang menggunakan model konvensional terlihat adanya kenaikan dan penurunan nilai dari tes akhir dan tes awal untuk nilai rataan, standar deviasi, nilai minimum, dan nilai maksimum. Pada tes awal untuk kelas standar deviasi kelas eksperimen didapat 0,773 sedangkan untuk tes akhirnya adalah 0,641 . 


\section{Analisis Data Korelasi Kemampuan Menulis Teks Deskripsi Berpikir Kreatif dengan Menggunakan Model Sinektik}

Untuk mengetahui seberapa besar hubungan antara variabel, perhitungan analisis korelasi menggunakan korelasi Pearson jika kedua data berdistribusi normal, dan menggunakan korelasi Rank-Spearman jika salah satu data tidak normal. Koefisien antara kemampuan menulis teks deskripsi dan berpikir kreatif menunjukkan tanda positif. Hal ini menunjukkan bahwa ada hubungan searah antar kedua kemampuan yang diuji. Artinya jika kemampuan menulis teks deskripsi, akan diikuti oleh meningkatnya kemampuan berpikir kreatif dengan koefisien relasi sebesar 0,556 dengan nilai signifikansi 0,000 .

\section{B. PEMBAHASAN}

\section{Kemampuan Menulis teks deskripsi}

Berdasarkan hasil analisis statistik pada Tes Awal, bahwa pemilihan kedua kelas yang dijadikan sebagai sampel penelitian berasal dari populasi yang homogen. Kemampuan menulis teks deskripsi pada kelompok siswa yang memperoleh pembelajaran dengan model sinektik dan konvensional dapat disimpulkan bahwa, tidak terdapat perbedaan yang signifikan kemampuan awal menulis teks dekripsi siswa yang memperoleh pembelajaran model sinektik dengan kemampuan siswa yang memperoleh pembelajaran konvensional. Hal ini menunjukan bahwa kemampuan awal menulis teks deskripsi siswa yang memperoleh pembelajaran model sinektik dan pembelajaran konvensional relatif sama.

Berdasarkan analisis terhadap tes akhir setelah dilaksanakan pembelajaran pada kedua kelas dengan pembelajaran yang berbeda yaitu menggunakan model sinektik dan pembelajaran konvensional dapat disimpulkan bahwa kemampuan menulis teks deskripsi siswa dengan menggunakan model sinektik lebih baik dibandingkan dengan siswa yang mengikuti pembelajaran konvensional.

Adapun kualitas kemampuan menulis teks deskripsi siswa yang menggunakan model sinektik dan konvensional berada pada kategori tinggi namun dengan rata-rata kualitas yang berbeda. Kelompok siswa yang menggunakan pembelajaran menggunakan model sinektik lebih besar daripada rataan kualitas peningkatan yang menggunakan pembelajaran konvensional.

Bagi kelas yang pembelajarannya mengggunakan model sinektik. Siswa mempunyai kebebasan dalam proses pembelajaran, siswa menjadi lebih aktif menggali potensi dalam diri mereka dalam mencari jawaban mengenai apa yang dipertanyakan.

Keberhasilan pembelajaran dengan model sinektik dalam kemampuan menulis teks deskripsi, karena pada pembelajaran ini guru guru tidak lebih dari fasilitator dan evaluator, sementara peran siswa lebih banyak dan aktif untuk berpikir mengkomunikasikan argumentasinya, mengoreksi jawaban mereka.

Keberhasilan model sinektik juga didukung oleh respon yang positif. Berdasarkan hasil analisis data angket skala sikap, secara keseluruhan sikap siswa terhadap pembelajaran menulis dengan model sinektik adalah positif, hal ini tersebut dimungkinkan karena pembelajaran menulis dengan model sinektik merupakan pengalaman belajar baru, pembelajaran bertitik tolak dari hal real, yang pernah dialami oleh siswa, belajar yang langsung berhadapan dengan dunia nyata, sehingga minat siswa terhadap pembelajaran menulis dengan model sinektik.

(Keraf, 1981:93). Pembelajaran menulis teks deskripsi dapat membantu siswa dalam melatih kepekaaan karena dengan menulis teks deskripsi, siswa da- 
pat menjelaskan secara nyata suatu objek ataupun suasana tertentu. Selain itu, siswa dapat menulis secara rinci unsurunsur, ciri-ciri dan struktur bentuk suatu benda secara konkret dalam bentuk teks yang dapat diinformasikan kepada pembaca. Hal ini juga didukung oleh hasil observasi yang menunjukkan kemampuan menulis teks deskripsi pada setiap pertemuan juga hasil wawancara terhadap beberapa orang yang menunjukkan kesukaan terhadap soal-soal teks deskripsi, mampu mengerjakannya, meskipun ada yang sempat kebingungan.

\section{Kemampuan Berpikir Kreatif}

Berdasarkan hasil analisis statistik pada tes awal, bahwa pemilihan kedua kelas yang dijadikan sebagai sampel penelitian berasal dari populasi yang homogen. Artinya tidak terdapat perbedaan kemampuan berpikir kreatif pada kelompok siswa yang memperoleh pembelajaran dengan model sinektik dan konvensional dapat disimpulkan bahwa, tidak terdapat perbedaan yang signifikan kemampuan awal berpikir kreatif siswa yang memperoleh pembelajaran model sinektik dengan kemampuan siswa yang memperoleh pembelajaran konvensional. Hal ini menunjukan bahwa kemampuan awal berpikir kreatif siswa yang memperoleh pembelajaran model sinektik dan pembelajaran konvensional relatif sama. Hal ini sangat membantu untuk melihat kemampuan berpikir kreatif siswa setelah pembelajara berlangsung.

Berdasarkan analisis terhadap tes akhir setelah dilaksanakan pembelajaran pada kedua kelas dengan pembelajaran yang berbeda yaitu menggunakan model sinektik dan pembelajaran konvensional dapat disimpulkan bahwa kemampuan berpikir kreatif siswa dengan menggunakan model sinektik lebih baik dibandingkan dengan siswa yang mengikuti pembelajaran konvensional. Berdsarkan analisis yang telah dilakukan, terdapat perbedaan kemampuan berpikir kreatif siswa yang menggunakan model sinektik dan konvensional.

Adapun kualitas kemampuan berpikir kreatif yang menggunakan model sinektik berada pada kategori tinggi namun dengan rata-rata kualitas yang berbeda. Kelompok siswa yang menggunakan pembelajaran model sinektik lebih besar daripada ratan kualitas yang menggunakan pembelajaran konvensional.

Bagi kelas yang pembelajarannya mengggunakan model sinektik. Siswa mempunyai kebebasan dalam proses pembelajaran, siswa menjadi lebih aktif menggali potensi dalam diri mereka dalam mencari jawaban mengenai apa yang dipertanyakan.

Keberhasilan pembelajaran dengan model sinektik dalam kemampuan berpikir kreatif, karena pada pembelajaran ini guru guru tidak lebih dari fasilitator dan evaluator, sementara peran siswa lebih banyak dan aktif untuk berpikir mengomunikasikan argumentasinya, dan mengoreksi jawaban mereka.

Keberhasilan model sinektik juga didukung oleh respon yang positif. Berdasarkan hasil analisis data angket skala sikap, secara keseluruhan sikap siswa terhadap pembelajaran menulis dengan model sinektik adalah positif, hal ini tersebut dimungkinkan karena pembelajaran menulis dengan model sinektik merupakan pengalaman belajar baru, pembelajaran bertitik tolak dari hal real, yang pernah dialami oleh siswa, belajar yang langsung berhadapan dengan dunia nyata, sehingga minat siswa terhadap pembelajaran menulis dengan model sinektik.

(Joyce \& weil, 2016:254) "Kemampuan berpikir kreatif siswa dapat dikembangkan dengan model sinektik karena adanya prinsip dan karakteristik model sinektik yang diterapkan dalam pembelajaran", misalnya, salah satu 
prinsip model sinektik yaitu prinsip aktivitas yang menganggap perlunya penemuan kembali suatu konsep menulis. Prinsip ini menghendaki siswa belajar menulis dengan mengalami sendiri (beraktivitas). Melalui aktivitas kreatif, kreativitas yang siswa miliki akan berkembang dengan baik.

Hal ini juga didukung oleh hasil observasi yang menunjukkan kemampuan menulis teks deskripsi pada setiap pertemuan juga hasil wawancara terhadap beberapa orang yang menunjukkan kesukaan terhadap soal-soal teks deskripsi, mampu mengerjakannya, meskipun ada yang sempat belum mengerti.

\section{Korelasi Kemampuan Menulis Teks Deskripsi dengan Berpikir Kreatif}

Korelasi antara menulis teks deskripsi dengan berpikir kreatif siswa yang menggunakan model sinektik dan yang menggunakan konvensional dicari dengan menggunakan korelasi. Diperoleh bahwa koefesien antara kemampuan menulis teks deskripsi dan berpikir kreatif menunjukan tanda positif. Hal ini menunjukkan bahwa ada hubungan searah antar kedua kemampuan yang diuji. Artinya kemampuan menulis teks deskripsi, akan diikuti oleh meningkatnya kemampuan berpikir kreatif dengan koefision relasi sebesar 0,556 dengan nilai signifikasi.

Berdasarkan hasil analisis pada siswa yang menggunakan model sinektik didapatkan bahwa terdapat korelasi antara menulis teks deskripsi dengan berpikir kreatif. Sedangkan untuk hasil analisis korelasi yang pembelajaran menggunakan konvensional didapat bahwa tidak terdapat korelasi yang erat antar menulis teks deskripsi dengan berpikir kreatif siswa.

Dari hasil wawancara didapatkan keterangan bahwa siswa merasa senag dan lebih tertarik dalam belajar menulis dengan menggunakan model sinektik walaupun pada awalnya siswa merasa bingung dan belum terbiasa, tapi seiring berjalanya waktu, siswa dapat beradaptasi dengan pembelajaran seperti ini. Dengan menggunakan pembelajaran ini, siswa menjadi lebih aktif dalam pembelajaran, baik aktif dalam mengemukakan ide/pendapat, bertanya ataupun mengerjakan soal yang diberikan guru. Pembelajaran ini juga mampu meningkatkan minat belajar dan ketertarikan siswa terhadap menulis, sehingga siswa yang berkemampuan rendah pun ikut serta dalam prose pembelajaran.

Faktor lain yang mempengaruhi adalah mindset siswa terhadap menmulis yang beranggapan bahwa menulis adalah pelajaran yang sulit, rumit, dan menakutkan sehinggga disaat pembejaran menulis dimulai siswa merasa cemas, apalagi jika siswa dihadapkan pada soal. Seperti yang disampaikan Kurniawan (2014:82) sebagai berikut.

Di sinilah siswa mengalami kesulitan. Kenyataan yang sering terjadi dalam pembelajaran: (1) setiap kali ada pembelajaran menulis cerita pasti siswa resah, kebingungan untuk menulis cerita tentang apa; (2) jika masalah yang akan diceritakan sudah ditemukan, siswa juga bingung untuk mengembangkan masalah ceritanya; (3) kebingungan itu membuat siswa merasa menulis adalah materi pelajaran yang lebih sulit dari pelajaran lain.

\section{Kendala Penelitian}

Kendala penulis dalam melaksanakan peneltian ini yaitu ketika diawal pertemuan siswa masih sering bertanya kepada guru, sehingga guru merasa kesulitan menjelaskan pada setiap orang. Untuk mengatasinya, saat guru akan menjawab pertanyaan dari setiap orang, guru meminta yang lainnya memperhatikan terlebih dahulu sehingga pertanyaan tidak berulang-ulang. Guru disarankan 
harus lebih mempersiapkan pengelolaan kelas yang lebih terencana dan terorganisir agar kegiatan pembelajaran menggunakan model sinektik dapat berjalan dengan baik.

Hampir sebagian besar siswa beranggapan bahwa menulis adalah pelajaran yang sulit, menakutkan dan rumit. Dengan mindset siswa seperti ini dapat menimbulkan resah, kebingungan untuk pembelajaran menulis. Selain itu, kendala yang dihadapi saat penelitian adalah waktu. Karena siswa belum terbiasa menggunakan model sinektik sehingga pada pembelajaran awal siswa masih bingung dan banyak bertanya. Sehingga pada pertemuan berikutnya mengan-tisipasi dengan memberikan arahan dan mengulas materi sebelumnya untuk me-ngingatkan siswa. Oleh karena itu pe-ngaturan waktu yang baik sangat diper-lukan untuk tercapainya materi pembe-lajaran.

Kemudian dalam pembelajaran biasanya siswa cenderung banyak ngobrolnya, jadi dalam hal ini guru harus sebisa mungkin mengatur siswa-siswa tersebut agar bisa bekerja dan belajar dengan kondusif.

Sebelum pelaksanaan pembelajaran pada penelitian ini banyak hal yang perlu peneliti siapkan, diantaranya media pembelajaran, namun demikan, kurangnya media dan alat peraga sebagai penunjang kegiatan pembelajaran menjadi salah satu kendala dalam penelitian ini. Keterbatasan tersebut membuat pembelajaran sedikit terlambat, dikarenakan siswa harus bergiliran dalam menggunakan alat peraga tersebut. Namun demikian tidak mengurangi antusias siswa dalam belajar, dan pembelajaran pun bisa terlaksana dengan baik. Kurangnya pengetahuan guru akan dunia nyata yang berkaitan dengan menulis juga menjadi salah satu kendala dalam penelitian ini. Pengetahuan guruakan du-nia nyata yang berkaitan dengan dunia nyata merupakan hal yang penting dalam pembelajaran menulis dengan model sinektik, dikarenakan hal tersebut dapat membuat pembelajaran menjadi lebih berkembang dengan munculnya masalah-masalah dari dunia nyata tersebut.

Di samping itu, pada pelaksanaannya, keterbatasan waktu juga menjadi kendala, selain karena alat peraga yang bergiliran, yang membuat sedikit terlambat, pembelajaran dengan model sinektik membutuhkan waktu yang banyak, kare-na proses menulis yang harus mengan-tarkan siswa dari masalah dunia nyata ke masalah menulis serta solusinya.

Keterbatasan sumber belajar yang tersedia menjadi kendala yang selanjutnya dalam penelitian ini, hal ini akan menghambat siswa dalam proses belajar terutama pada saat fase mengidentifikasi konsep analogi yang relevan dengan masalah, lalu mengorganisasi masalah sesuai dengan konsep analogi. Akan tetapi hal tersebut bisa sedikit teratasi dengan tersedianya jaringan internet, sehingga memudahkan siswa untuk mencari sumber belajar.

\section{SIMPULAN}

Berdasarkan hasil penelitian dan pembahasan mengenai pembelajaran Model Sinektik Berorientasi Berpikir Kreatif dalam Pembelajaran Menulis Teks Deskrpisi Siswa SMP, maka dapat disimpulkan bahwa:

1) Kemampuan menulis teks deskripsi siswa yang menggunakan model sinektik lebih baik dibandingkan dengan siswa yang menggunakan pembelajaran konvensional meliputi indikator kelengkapan isi, keterlibatan pancaindra, pilhan kata, ejaan dan tanda baca, dan kerapihan tulisan

2) Kemampuan menulis teks deskripsi siswa yang menggunakan pembelajaran model sinektik lebih baik diban- 
dingkan dengan siswa yang menggunakan pembelajaran konvesional.

3) Kemampuan berpikir kreatif siswa yang menggunakan pembelajaran model sinektik lebih baik dibandingkan dengan siswa yang menggunakan pembelajaran konvensional.

4) Terdapat kolerasi antara kemampuan menulis teks deskripsi dengan berpikir kreatif siswa yang menggunakan pembelajaran model sinektik dengan yang menggunakan pembelajaran konvensional.

5) Berdasarkan hasil analisis, wawancara, dan observasi didapatkan hasil bahwa siswa yang menggunakan model sinektik lebih aktif dalam belajar, baik aktif dalam bertanya, menjawab ataupun menyelesaikan permasalahan yang diberikan, siswa mempunyai kebebasan dalam berpendapat. Aktifitas siswa menjadi lebih terarah dengan adanya peran guru, dalam hal ini guru berperan sebagai fasilitator sehingga guru harus lebih terampil dalam mengkonsisikan kelas. Berbeda hal dengan siswa yang menggunakan model pembelajaran konvensional, guru memiliki peran yang lebih dominan karena siswa hanya mendengarkan dan memperhatikan apa yang disampaikan oleh guru saja.

\section{DAFTAR PUSTAKA}

Alwasiah, A. C. dan Senny S. A. (2007) Pokoknya menulis. Bandung: Kiblat.

Indrawan, Rully dan Poppy Yaniawati. (2014). Metodologi penelitian. Bandung: Refika Aditama.

Joyce, dkk. (2011). Model of teaching. Yogjakarta: Pustaka Pelajar.

Keraf, Gorys. (1981). Eksposisi dan deskripsi. Jakarta: Nusa Indah
Kurniawan, Heru. (2014). Pembelajaran menulis kreatif. Bandung: Remaja Rosdakarya

Munir. (2008). Kurikulum berbasis teknologi informasi dan komunikasi. Bandung: Alphabeta

Santoso. (1990). Problematika Bahasa Indonesia. Jakarta: Rineka Cipta.

Tarigan, H. G. (2008). Menulis sebagai suatu keterampilan berbahasa. Bandung: Angkasa.

Waluyo, B. (2003). Bahasa dan sastra Indonesia. Jakarta: Tiga Serangkai Pustak Mandiri. 